\title{
Article \\ Key Physicochemical Determinants in the Antimicrobial Peptide RiLK1 Promote Amphipathic Structures
}

\author{
Lucia Falcigno ${ }^{1,+}$, Gabriella D'Auria ${ }^{1,+}$, Gianna Palmieri ${ }^{2, *}\left(\mathbb{C}\right.$, Marta Gogliettino $^{2, *}$, Bruna Agrillo ${ }^{2,3,4}$, \\ Rosarita Tatè ${ }^{5}$, Principia Dardano ${ }^{6}{ }^{\mathbb{C}}$, Luigi Nicolais ${ }^{3}$ and Marco Balestrieri ${ }^{2}{ }^{(1)}$ \\ 1 Department of Pharmacy, University of Naples Federico II, Via D. Montesano 49, 80131 Naples, Italy; \\ lucia.falcigno@unina.it (L.F.); gabriella.dauria@unina.it (G.D.) \\ 2 Institute of Biosciences and BioResources, National Research Council (IBBR-CNR), Via Pietro Castellino 111, \\ 80131 Naples, Italy; bruna.agrillo@ibbr.cnr.it (B.A.); marco.balestrieri@ibbr.cnr.it (M.B.) \\ 3 Materias Srl, Corso N. Protopisani 70, 80146 Naples, Italy; nicolais@unina.it \\ 4 Department of Biology, University of Naples Federico II di Monte Sant'Angelo, Via Cintia 21, \\ 80126 Naples, Italy \\ 5 Institute of Genetics and Biophysics, National Research Council (IGB-CNR), Via Pietro Castellino 111, \\ 80131 Naples, Italy; rosarita.tate@igb.cnr.it \\ 6 Institute of Applied Sciences \& Intelligent Systems, National Research Council (ISASI-CNR), Via Pietro \\ Castellino 111, 80131 Naples, Italy; principia.dardano@na.isasi.cnr.it \\ * Correspondence: gianna.palmieri@ibbr.cnr.it (G.P.); marta.gogliettino@ibbr.cnr.it (M.G.); \\ Tel.: +39-081-613-2711 (G.P.); +39-081-613-2279 (M.G.) \\ + These authors contributed equally to this work.
}

\section{check for} updates

Citation: Falcigno, L.; D'Auria, G.; Palmieri, G.; Gogliettino, M.; Agrillo, B.; Tatè, R.; Dardano, P.; Nicolais, L.; Balestrieri, M. Key Physicochemical Determinants in the Antimicrobial Peptide RiLK1 Promote Amphipathic Structures. Int. J. Mol. Sci. 2021, 22, 10011. https://doi.org/10.3390/ ijms221810011

Academic Editor: Oxana

V. Galzitskaya

Received: 26 July 2021

Accepted: 14 September 2021

Published: 16 September 2021

Publisher's Note: MDPI stays neutral with regard to jurisdictional claims in published maps and institutional affiliations.

Copyright: (c) 2021 by the authors. Licensee MDPI, Basel, Switzerland. This article is an open access article distributed under the terms and conditions of the Creative Commons Attribution (CC BY) license (https:// creativecommons.org/licenses/by/ $4.0 /)$.

\begin{abstract}
Antimicrobial peptides (AMPs) represent a skilled class of new antibiotics, due to their broad range of activity, rapid killing, and low bacterial resistance. Many efforts have been made to discover AMPs with improved performances, i.e., high antimicrobial activity, low cytotoxicity against human cells, stability against proteolytic degradation, and low costs of production. In the design of new AMPs, several physicochemical features, such as hydrophobicity, net positive charge, propensity to assume amphipathic conformation, and self-assembling properties, must be considered. Starting from the sequence of the dodecapeptide 1018-K6, we designed a new 10-aminoacid peptide, namely RiLK1, which is highly effective against both fungi and Gram-positive and -negative bacteria at low micromolar concentrations without causing human cell cytotoxicity. In order to find the structural reasons explaining the improved performance of RiLK1 versus 1018-K6, a comparative analysis of the two peptides was carried out with a combination of $C D, N M R$, and fluorescence spectroscopies, while their self-assembling properties were analyzed by optical and atomic force microscopies. Interestingly, the different spectroscopic and microscopic profiles exhibited by the two peptides, including the propensity of RiLK1 to adopt helix arrangements in contrast to 1018-K6, could explain the improved bactericidal, antifungal, and anti-biofilm activities shown by the new peptide against a panel of food pathogens.
\end{abstract}

Keywords: AMP; NMR; stereomicroscopy; CD; atomic force microscopy (AFM); fluorescence; selfassembling; conformation distribution

\section{Introduction}

In recent decades, growing interest in antimicrobial peptides (AMPs) for their applications as bactericidal agents in different fields has been observed. Firstly, the increased bacterial resistance due to the uncontrolled use of antibiotics has raised significant concerns in medicine, encouraging research into novel therapeutics [1-3]. In this scenario, AMPs are considered a promising new class of antibiotics [4]. Moreover, another relevant application of AMPs is that in the food industry as antimicrobials [5-11], bio-preservatives [12], and anti-biofilm agents $[3,13,14]$. Indeed, AMPs, also known as host defense peptides 
(HDPs), are an important group of natural substances widely distributed in nature, offering a broad spectrum of activity against Gram-positive and Gram-negative bacteria, viruses, fungi, and parasites [2]. A wide variety of organisms, ranging from prokaryotes to humans, produce AMPs as a part of their first line of defense [15]. In addition, AMPs isolated from natural sources as well as their synthetic variants have revealed their broad-spectrum antimicrobial activity [16-18]. AMPs are small, predominantly cationic and amphipathic polypeptides, with different compositions, molecular masses and secondary structures $[2,13]$. However, AMPs exhibit several structural characteristics which are essential for their activity [17]. First, to interact with and penetrate bacterial membranes, AMPs must show a right balance of positive charge and hydrophobicity $[19,20]$. Indeed, the net positive charge enables electrostatic attractions between AMPs and the negatively charged microbial membranes, whilst hampering the interactions with the neutrally charged mammalian cell membranes [15,21-23]. At the same time, the hydrophobicity of AMPs allows them to penetrate cells, inducing membrane lysis [24,25]. Due to the complexity of peptide-membrane interaction, the hydrophilicity/hydrophobicity properties must be finely balanced to optimize the activity and selectivity of AMPs avoiding cytotoxicity [20]. In this regard, the conformational features of AMPs play a key role $[4,26]$. Peptides show different conformations and aggregation states in free or in membranebound form [4,27]. Such items deeply influence the efficacy and selectivity of AMPs. Specifically, the self-assembling properties of AMPs have received increasing attention in the rational design and engineering of smart AMPs [28-32].

Recently, Palmieri et al. [33] projected a peptide, namely 1018-K6, designed on the basis of the dodecapeptide IDR-1018, a natural derivative of a bovine HDP bactenecin, which belongs to the cathelicidins family [34]. Cathelicidins are small, cationic, antimicrobial peptides found in humans and other species, including farm animals. The only cathelicidin in humans is the cationic protein of $18 \mathrm{kDa}$ (hCAP18), which is expressed in neutrophils, monocytes, and epithelial cells [35], stored as an inactive precursor and processed to generate the active peptide LL-37 [35]. These proteolytically activated peptides are part of the innate immune system in many vertebrates and show a broad spectrum of antimicrobial activity against bacteria, enveloped viruses and fungi. Apart from exerting direct antimicrobial effects, cathelicidins can also trigger specific defense responses in the host [35].

Although native IDR-1018 shows a broad spectrum of antimicrobial and anti-biofilm activity [36-39], the analogue 1018-K6 revealed a stronger efficiency than IDR-1018 in eradicating and inhibiting biofilm growth as well as in killing the planktonic cells of Listeria strains isolated from food-products and food-processing environments [33,40]. On these grounds, to further improve the structural features and the antibacterial performances of 1018-K6 peptide, some modifications were planned taking into account (i) to shorten the peptide length in order to reduce the costs of production and to improve the stability and safety; (ii) to take the proper content of basic and hydrophobic residues; and (iii) to ensure the formation of an amphipathic helix. The best obtained analogue, a decapeptide named RiLK1 (RLKWVRIWRR-NH2), has been synthesized and characterized [41]. RiLK1 was highly effective against both fungi and Gram-positive and -negative bacteria, with no evidence of cytotoxicity on human keratinocytes and fibroblasts.

In this paper, we reported the structural characterization of RiLK1 and 1018-K6 peptides in water and in SDS micellar solutions carried out by a combination of NMR, CD and fluorescence spectroscopic techniques. As generally observed for AMPs, conformational changes are observed moving from pure water to micellar environments as well as for our peptides, even though they show different structural behavior. In order to investigate their propensity for self-assembling, RiLK1 and 1018-K6 were analyzed by optical and atomic force microscopies. Our results point out a conformational propensity of RiLK1 to self-assemble in regular structures more than 1018-K6. This structural finding could explain the excellent bactericidal, antifungal and anti-biofilm activities exhibited by RiLK1 in comparison to 1018-K6 against a panel of food-pathogens [41]. 


\section{Results}

\subsection{Molecular Design of RiLK1 Peptide}

AMPs are known to be highly variable in terms of size and sequence and can be classified according to their secondary structure ( $\alpha$-helix, $\beta$-sheet, etc.) $[15,42]$. These peptides are rich in basic amino acids (Lys, Arg) that confer an overall net charge ranging from +2 to +9 , and they possess approximately $50 \%$ hydrophobic residues, which may favor an amphipathic conformation upon interaction with membranes [4].

Specifically, the amphipathic topology is considered a key aspect for the AMP's mechanism of action. Indeed, in this state, the positively charged surface of AMP guarantees the contact with the negatively charged surface of the bacterium, while its hydrophobic surface can get in touch with the internal portions of the membrane, destabilizing and finally breaking it [43].

When designing a new AMP, Arg and Trp residues are preferred among positively charged and hydrophobic amino acids, respectively, for their properties of interaction with the bacterial membranes [18]. Indeed, the Arg residue endows the peptides with cationic charges, and it has a higher $\mathrm{pKa}$ and multi-dentate hydrogen bonding properties that favor the interaction with membranes compared to Lys [43-46]. As regards the Trp residue, the flat rigid shape and the aromaticity (i.e., its $\pi$ electron structure and associated electrical quadrupole moment) of side-chain promote its penetration and residing in the interface environment $[18,46]$.

Based on all these evidences, the peptide RiLK1 (RLKWVRIWRR-NH ${ }_{2}$ ) was de novo designed starting from the 1018-K6 sequence (VRLIVKVRIWRR-NH $\mathrm{N}_{2}$ [33]. The new decapeptide analogue holds the last six C-terminal residues of the parent dodecapeptide 1018-K6, while in the N-terminal portion, it is shortened by three residues and modified by the insertion of a Trp residue [41]. It is worth noting that the molecular design has successfully produced a more performing AMP, as RiLK1 exhibits greatly improved antimicrobial efficiency compared to the parent 1018-K6 [41].

\subsection{Solid-State Analysis of RiLK1 and 1018-K6 by AFM and Optical Microscopy}

The self-assembling properties of RiLK1 and 1018-K6 peptides were evaluated by atomic force microscopy (AFM) and stereomicroscopy.

The AFM study was performed on washed and dried samples (see Materials and Methods section for the detailed sample preparation) obtained from peptides solved in PBS and in water in order to compare the aggregation tendency of both molecules in the presence or absence of salts. Sample preparation provides the gentle and extensive rinsing of the surface with deionized water ( $5 \mathrm{~mL}$ per sample), which ensures the complete removal of salt crystals and the quote of peptide not bound on mica surface.

In both environments, RiLK1 self-aggregates in linearly ordered structures (Figure 1), which are more tightly distributed on the mica surface when obtained from water than from PBS (see Figure 1A,B vs. E,F), although the heights of the aggregates are identical $(\approx 6 \mathrm{~nm})$, as shown in the profiles reported in Figure $1 \mathrm{C}, \mathrm{D}, \mathrm{G}, \mathrm{H}$.

On the other hand, 1018-K6 self-assembles in linearly ordered structures (Figure 2) from water with a mean height of approximately $8 \mathrm{~nm}$ (Figure 2C,D), whilst in PBS a diffuse thin layer of molecules with a height of about $1 \mathrm{~nm}$ is observed (Figure $2 \mathrm{G}, \mathrm{H}$ ).

The propensity of peptides to self-assembling was also investigated by stereomicroscopy. This analysis, performed on dried samples obtained from RiLK1 and 1018-K6 solutions at different concentrations $(40,80,160,240 \mu \mathrm{M})$ in PBS and in phosphate buffer (PB) indicates that the two peptides self-assemble in structures of different shapes, where, in the presence of salt, 1018-K6 aggregates in flat layers, while RiLK1 aggregates by forming tri-dimensional structures (Supplementary Figures S1 and S2). 

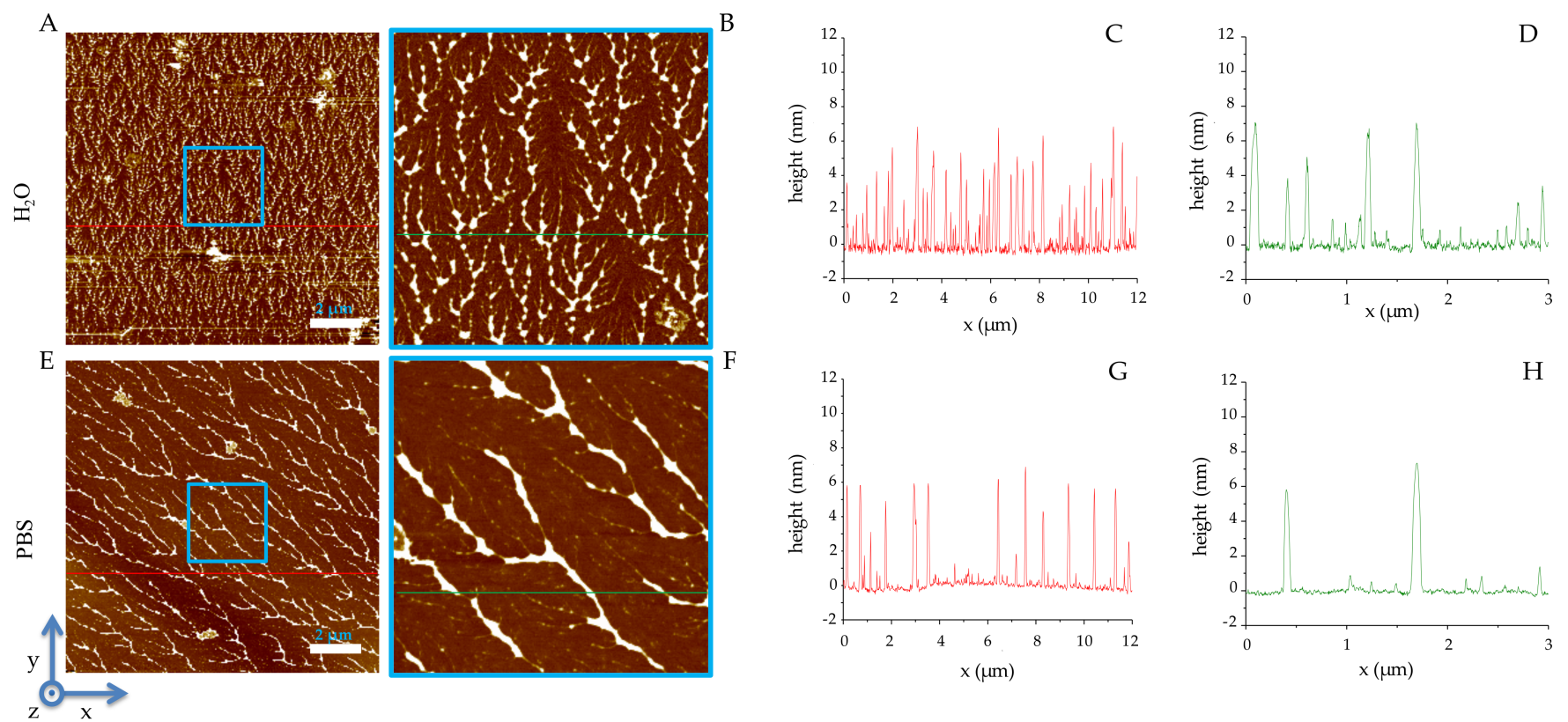

Figure 1. AFM images of RiLK1. (A) $12 \mu \mathrm{m} \times 12 \mu \mathrm{m}$ field image of dried water solution of RiLK1, the scale bar is $2 \mu \mathrm{m}$, the blue square locates the $3 \mu \mathrm{m} \times 3 \mu \mathrm{m}$ field reported in image (B); heights referred to by the red line in (A) are reported in the graph line in $(C)$ and the heights referred to by the green line in (B) are reported in the graph line in (D); (E) $12 \mu \mathrm{m} \times$ $12 \mu \mathrm{m}$ field image of dried PBS solution of RiLK1, the scale bar is $2 \mu \mathrm{m}$, the blue square locates the $3 \mu \mathrm{m} \times 3 \mu \mathrm{m}$ field reported in image $(\mathbf{F})$; heights referred to by the red line in $(\mathbf{E})$ are reported in the graph line in $(\mathbf{G})$ and heights referred to by the green line in $(\mathbf{F})$ are reported in the graph line in $(\mathbf{H})$.
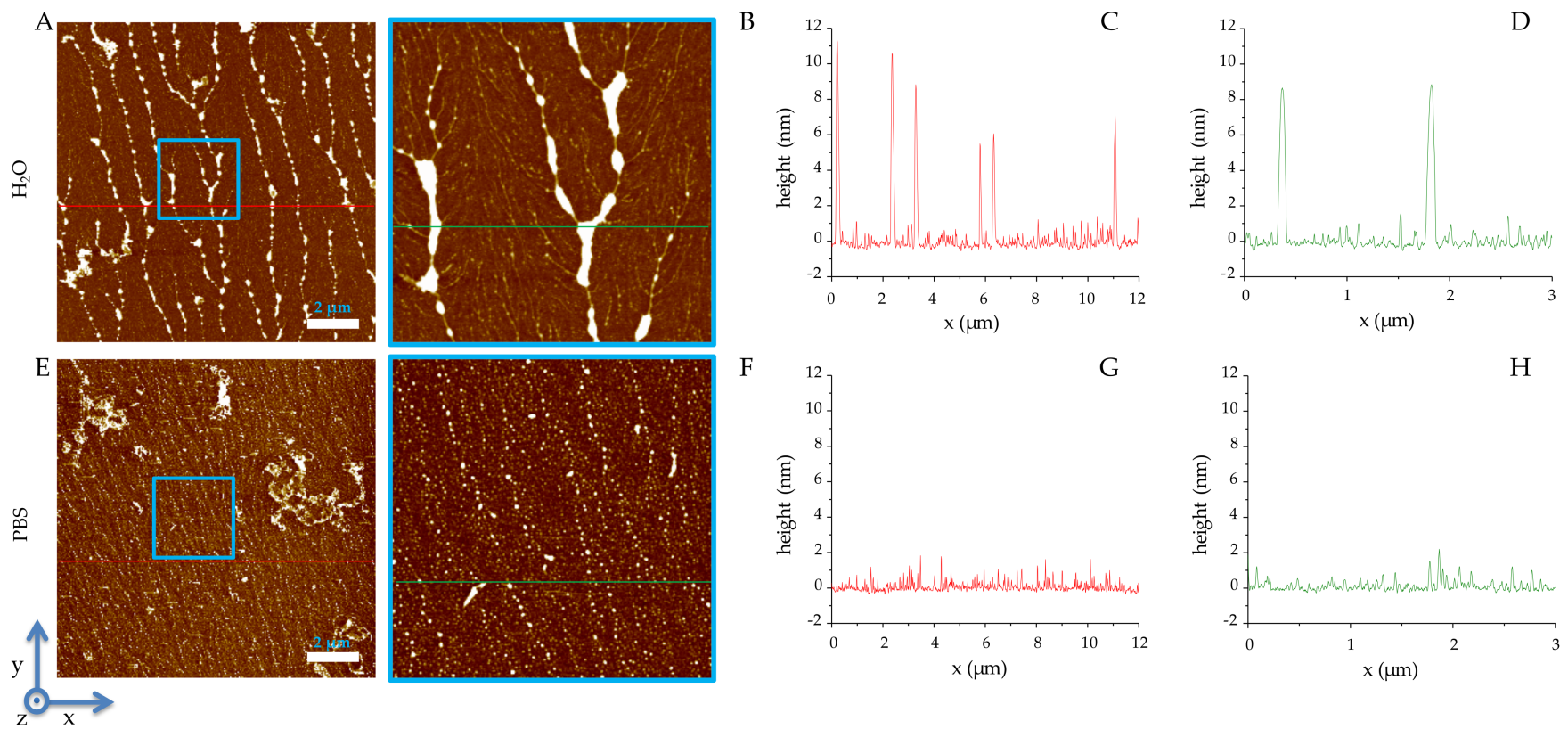

Figure 2. AFM images of 1018-K6. (A) $12 \mu \mathrm{m} \times 12 \mu \mathrm{m}$ field image of dried water solution of RiLK1, the scale bar is $2 \mu \mathrm{m}$, the blue square locates the $3 \mu \mathrm{m} \times 3 \mu \mathrm{m}$ field reported in image (B); heights referred to by the red line in (A) are reported in graph line in (C) and heights referred to by the green line in (B) are reported in graph line in (D); (E) $12 \mu \mathrm{m} \times 12 \mu \mathrm{m}$ field image of dried PBS solution of RiLK1, the scale bar is $2 \mu \mathrm{m}$, the blue square locates the $3 \mu \mathrm{m} \times 3 \mu \mathrm{m}$ field reported in image $(\mathbf{F})$; heights referred to by the red line in $(\mathbf{E})$ are reported in graph line in $(\mathbf{G})$ and heights referred to by the green line in $(\mathbf{F})$ are reported in graph line in $(\mathbf{H})$. 


\subsection{Structural Analysis of RiLK1 and 1018-K6 by CD and Fluorescence Spectroscopies}

In order to study the structural features of RiLK1 and 1018-K6 and their aptitude to interact with membranes, an extensive spectroscopic investigation was performed by $C D$ and fluorescence spectroscopies in water and in SDS micelles, a widely used model system to study interactions between AMPs and cell membranes [9,10,33,40,41,47-49]. It is worth noting that this surfactant may be suitable for all the spectroscopic techniques performed in this work and even more for NMR analysis in solution. In addition, our results can easily be compared with the extensive literature on AMPs, which reports the functional data combined with studies in SDS micellar solutions [9,10,33,40,41,47-49].

The behavior of the two peptides in response to various factors such as SDS concentration, SDS/peptide ratios, $\mathrm{pH}$ values, and incubation time was examined.

\subsubsection{Effect of SDS Concentration on Peptide Structure}

The CD spectra of the two peptides in water and in the presence of different concentrations of SDS are shown in Figure 3A,B. Spectral data were analyzed using the K2D software to estimate the contributions to the spectrum of the secondary structure elements $\alpha$-helix, $\beta$-sheet, and coil [50].

A

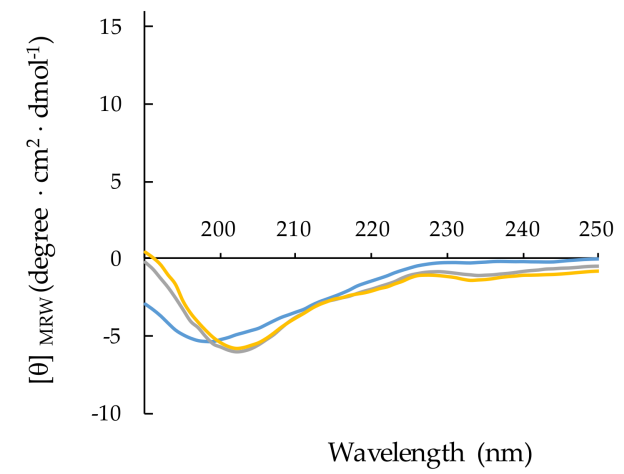

$\mathrm{C}$

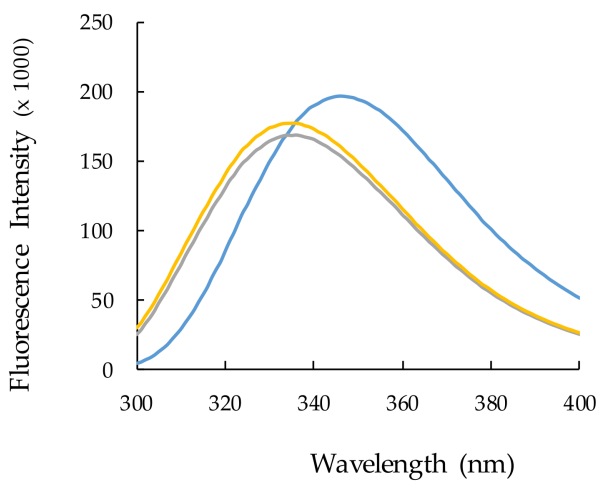

B
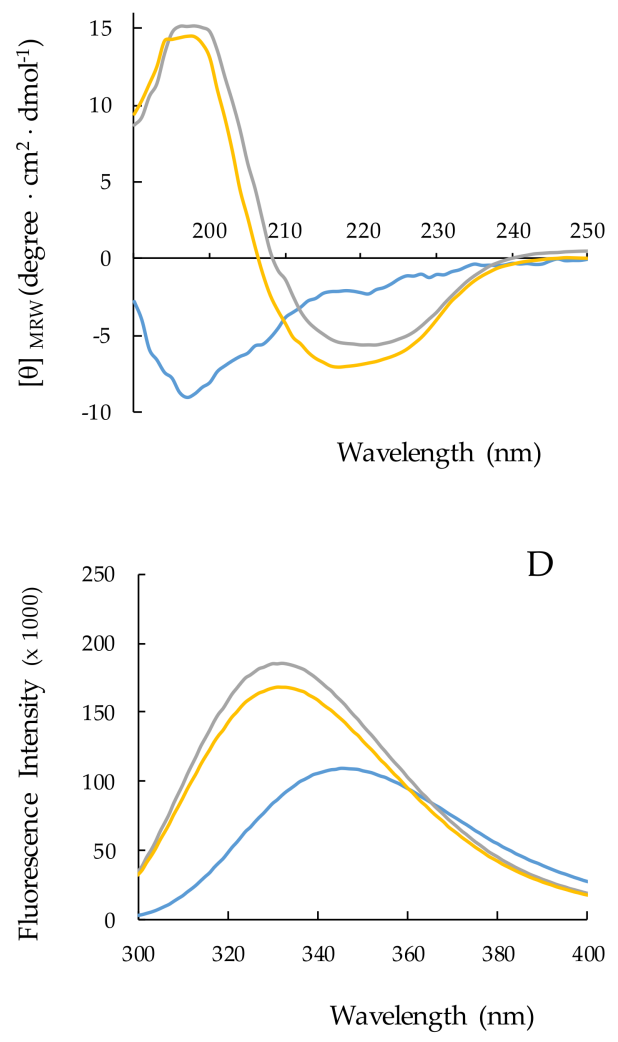

Figure 3. CD and fluorescence spectra of RiLK1 and 1018-K6. RiLK1 (A,C) and 1018-K6 (B,D) were analyzed at increasing SDS concentration. Spectra were recorded at peptide concentration of $50 \mu \mathrm{M}$, $\mathrm{pH} 4.0$ and $25^{\circ} \mathrm{C}$ in the absence of SDS (blue lines) and in the presence of SDS $50 \mathrm{mM}$ (gray lines) or $150 \mathrm{mM}$ (yellow lines).

RiLK1 (Figure 3A) and 1018-K6 (Figure 3B) adopt in water a random coil conformation as indicated by the presence in the CD spectra of a negative band at $198 \mathrm{~nm}$. The addition of SDS to the peptide solutions induces spectral variations that are different for the two peptides. Concerning RiLK1, the minimum shifts to $\sim 204 \mathrm{~nm}$ and a shallower negative peak appears at $\sim 235 \mathrm{~nm}$ upon the addition of 50 or $150 \mathrm{mM}$ SDS. These variations reveal that SDS induces changes in the peptide conformational distribution by somehow stabilizing 
the ordered structures $\alpha$-helix (27\%) and $\beta$-sheet (37\%) with respect to the random coil structure (40\%) (Figure 3A, Supplementary Table S1). A different behavior was observed for 1018-K6 which responds to the presence of SDS stabilizing at 100\% in $\beta$-structure. It is worth noting that the use of prediction algorithms to estimate the secondary structure composition from CD spectra often fails to provide adequate results on $\alpha / \beta$-mixed or $\beta$-structure peptides. However, the CD conformational distributions observed for the two peptides in the presence of SDS provided structural clues that were confirmed by the NMR analyses.

To complement the $\mathrm{CD}$ data, the same analyses were performed by fluorescence, taking advantage of the presence of tryptophan residues in both peptide sequences. In water, the maximal fluorescence emission ( $\lambda$ max) for both peptides was observed at $\sim 350 \mathrm{~nm}$, a value that is typical for Trp indole group fully exposed to hydrophilic environments. The addition of SDS causes a blue shift of $\lambda \max$ from 350 to $335 \mathrm{~nm}$ in the fluorescence spectra of both peptides (Figure 3C,D). This effect is observed when the tryptophan side chain shifts from a hydrophilic to a less polar and/or less dynamic surrounding solvent. However, the two peptides display changes in fluorescence intensity of opposite signs with the transfer from the aqueous to the SDS environment. Indeed, while 1018-K6 shows an increase in the fluorescence intensity consistent with a decreased flexibility of its Trp residue, a quench in the emission band was evidenced for RiLK1, probably suggesting that one or both Trp residues are involved in hydrophobic interactions in the micellar solutions.

Taken together, the CD and fluorescence analyses suggest that both peptides are able to interact with SDS micelles, even though stabilizing in different type conformations: i.e., $\alpha$-helix for RiLK1, $\beta$-sheet for 1018-K6.

\subsubsection{Peptide-SDS Interaction: The Peptide Concentration Effect}

The dependence of peptide-micelle interaction on the peptide concentration was followed by $\mathrm{CD}$ and fluorescence. Spectra were acquired at 12.5, 25 and $50 \mu \mathrm{M}$ concentration of each peptide in $50 \mathrm{mM}$ SDS, at pH 4.0 (Supplementary Figures S3 and S4).

Regarding the CD behavior of RiLK1, the spectral analysis obtained by K2D shows an increase in the $\alpha$-helix component at the expense of the $\beta$-sheet structure, as the concentration of the peptide increases (Supplementary Table S2A). On the opposite, 1018-K6 predominantly folded in $\beta$-sheet conformation upon titration with increasing peptide concentrations (Supplementary Table S2B). In the fluorescence spectra, the extent of the $\lambda \max$ blue shift is independent of the concentration of the peptide, whether it is RiLK1 or 1018 K6 (Supplementary Figures S3 and S4). However, the fluorescence intensities change with an opposite trend for the two peptides. As the concentration of 1018-K6 increases, the emission intensity rises while for RiLK1, the increment in the peptide concentration causes a decrease in the fluorescence band (quenching).

In summary, the CD investigation shows that in the presence of SDS, and at increasing concentrations, both peptides stabilize in more ordered, albeit different, structures: $\alpha$-helix for RiLK1 and $\beta$-sheet for 1018-K6. Furthermore, the fluorescence data suggest that RiLK1 interacts with the SDS micelle better than 1018-K6.

\subsubsection{Peptide-SDS Interaction: Time Effect}

We studied the peptide folding kinetics of RiLK1 and 1018-K6 in the presence of $150 \mathrm{mM}$ SDS during the $24 \mathrm{~h}$ incubation. The CD spectra (Figure $4 \mathrm{~A}, \mathrm{~B}$ ) evidence that each peptide retains its own conformational distribution (Supplementary Table S3A,B) during the time. Conversely, the fluorescence spectra (Figure 4C,D) change significantly over time, showing a decrease in the signal intensity for both peptides. This quenching was probably due to self-assembling or the strengthening of interactions with SDS micelles, or both. 
A

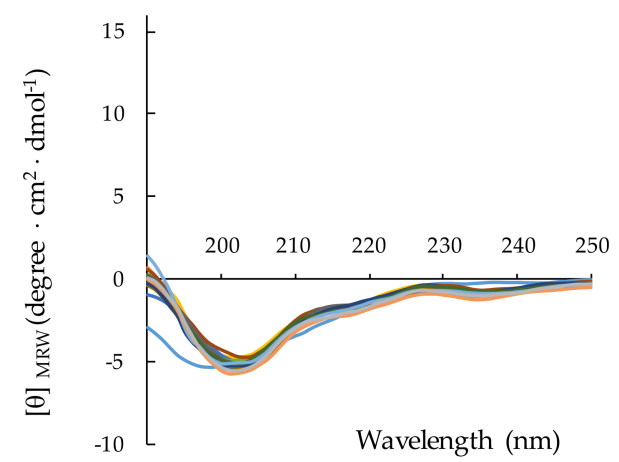

C

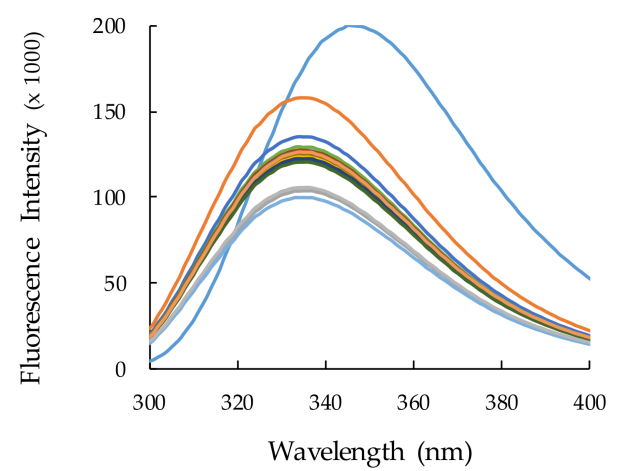

B
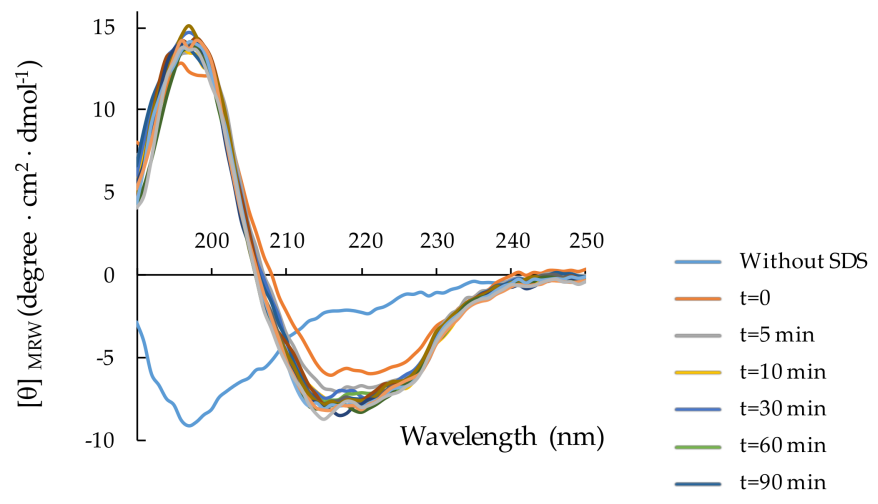

D $\quad \mathrm{t}=120 \mathrm{~min}$
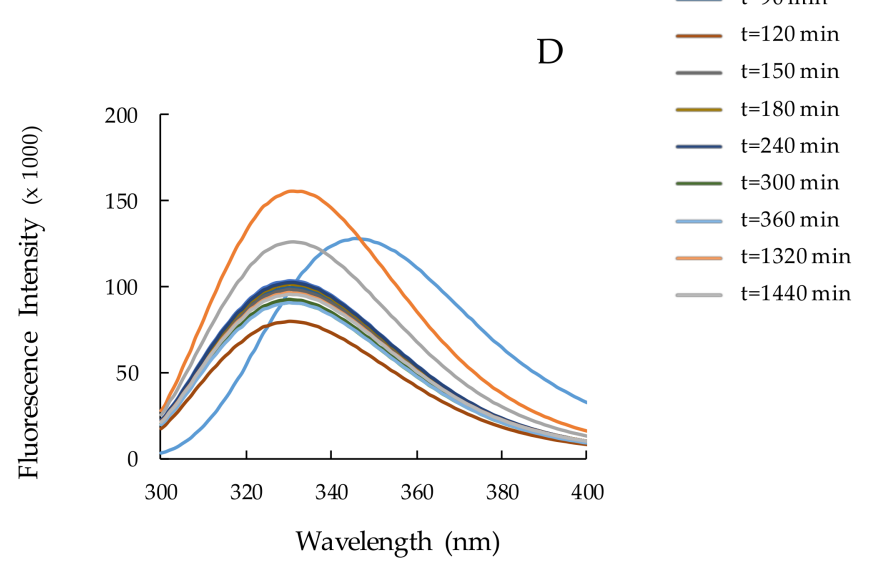

Figure 4. CD and fluorescence spectra of RiLK1 and 1018-K6. RiLK1 (A,C) and 1018-K6 (B,D) were analyzed as a function of time. Spectra were recorded at a peptide concentration of $50 \mu \mathrm{M}$ in $150 \mathrm{mM} \mathrm{SDS}$, at pH 4.0 and at $25^{\circ} \mathrm{C}$ after up to $24 \mathrm{~h}$ incubations. Spectra of peptides $50 \mu \mathrm{M}$ in water, without SDS (blue lines), were also reported.

\subsubsection{Peptide-SDS Interaction: $\mathrm{pH}$ and Temperature Effects}

Finally, as the antibacterial activity of many AMPs is attenuated by several physicochemical parameters, the conformational stability of RiLK1 and 1018-K6 at different $\mathrm{pH}$ and temperatures for $48 \mathrm{~h}$ in SDS micellar solutions was investigated (Supplementary Figures S5 and S6). As far as 1018-K6 is concerned, the dichroic spectra clearly manifest a stabilization of $\beta$-sheet conformation at acidic and neutral $\mathrm{pH}$ (Supplementary Figure S5A,B and Supplementary Table S4A), with fractional helicity increasing from $\sim 9 \%$ to $60 \%$ over experimental time span - but only at basic $\mathrm{pH}$ values (Supplementary Figure S5C and Supplementary Table S4A). On the contrary, RiLK1 evidences a dynamic equilibrium among different folds, at the different $\mathrm{pH}$ levels over $48 \mathrm{~h}$ incubation (Supplementary Figure $\mathrm{S6}$ and Supplementary Table S4B). As for the fluorescence data, the maximal fluorescence intensity and the fluorescence emission maximum in the presence of micelles are independent of the $\mathrm{pH}$ values both for RiLK1 and 1018-K6, indicating that emitting tryptophan residues are located in similar environments, except for RiLK1 at acidic $\mathrm{pH}$ values that produced a decrease in fluorescence quantum yields (Supplementary Figures S5 and S6).

A high structural and folding stability was observed, also subjecting RiLK1 and 1018-K6 to thermal treatments that did not induce any significant changes in the CD and fluorescence spectra at all the temperatures investigated, although 1018-K6 seemed to be less thermally stable at $90^{\circ} \mathrm{C}$ with respect to RiLK1 (Supplementary Figures S7 and S8, and Supplementary Table S5).

\subsection{Structural Analysis of RiLK1 and 1018-K6 by NMR}

\subsubsection{NMR Analysis in Water}

One-dimensional NMR spectra are in the Supplementary Material (Supplementary Figure S9). 
NMR data, such as the deviations of the $\alpha \mathrm{CH}$ proton chemical shift (Supplementary Figure S10) from random coil values [51] and NOEs, collected for RiLK1 and 1018-K6 in $\mathrm{H} 2 \mathrm{O} / \mathrm{D} 2 \mathrm{O} 90 / 10$ at $\mathrm{pH} 4$, indicate random coil conformations of both peptides. This structural diagnosis was confirmed by the molecular models computed by the CYANA program [52] using NOE-derived distances as the upper limit (upl) of interproton distances (for details see Table 1). The best 40 CYANA structures in terms of agreement with experimental data, i.e., with the lowest target function (TF) values (Table 1), were clustered by the CHIMERA program [53]. The structures contained in the first most-populated clusters were chosen as representative of the conformational space accessible to the peptides and reveal a huge conformational flexibility of RiLK1 (Figure 5A,B) and 1018-K6 (Figure 6) in pure water.
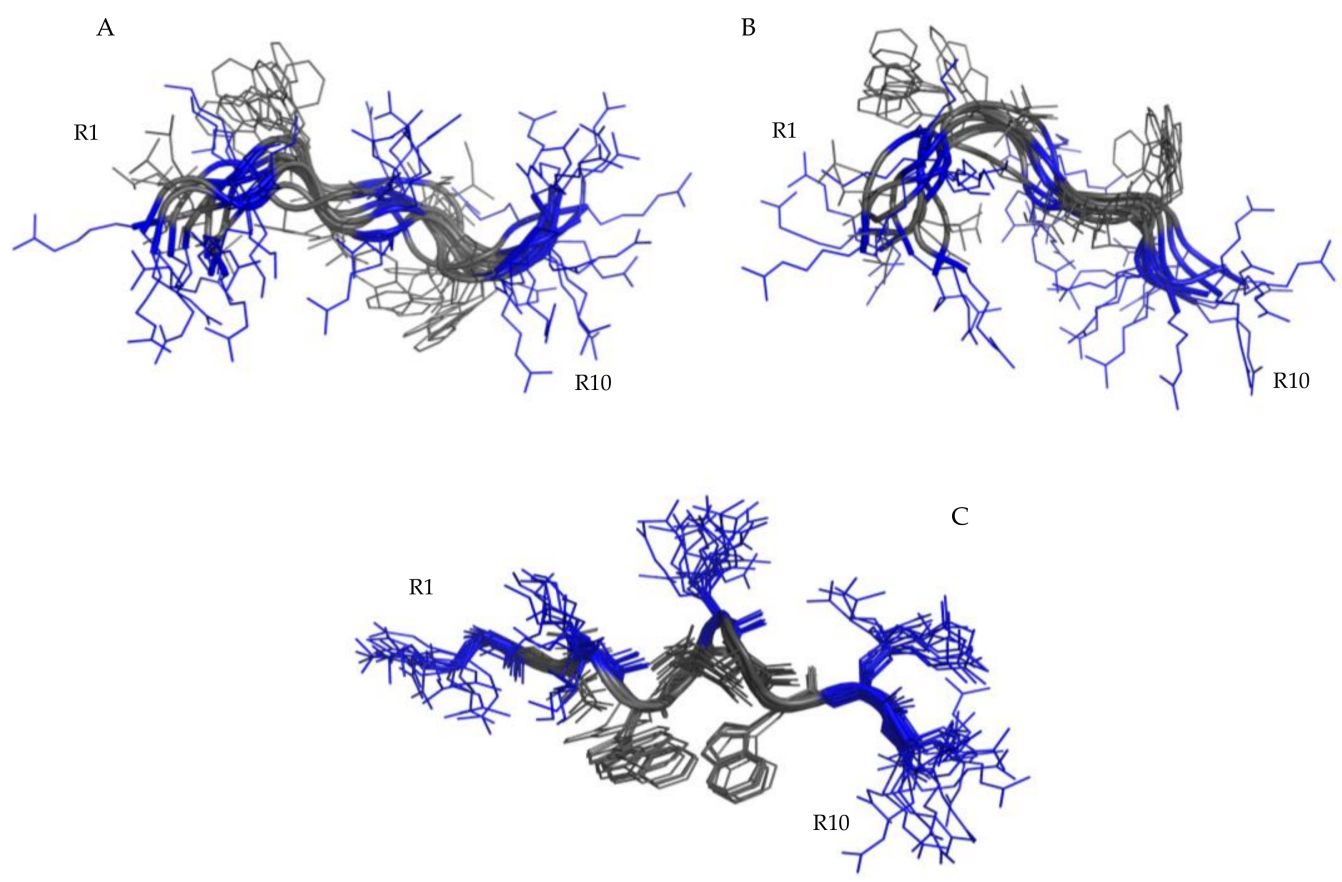

Figure 5. NMR structures of RiLK1. Superimposition of structures belonging to the first two Chimera clusters representative of RiLK1 conformation in water: (A) cluster 0, 9 models; (B) cluster 1, 8 models; (C) superimposition of 20 structures belonging to the main Chimera cluster representative of RiLK1 conformation in SDS. Cartoon representation with hydrophobic side-chains as lines colored in gray and positive charged $(\mathbf{R}, \mathbf{K})$ in blue.

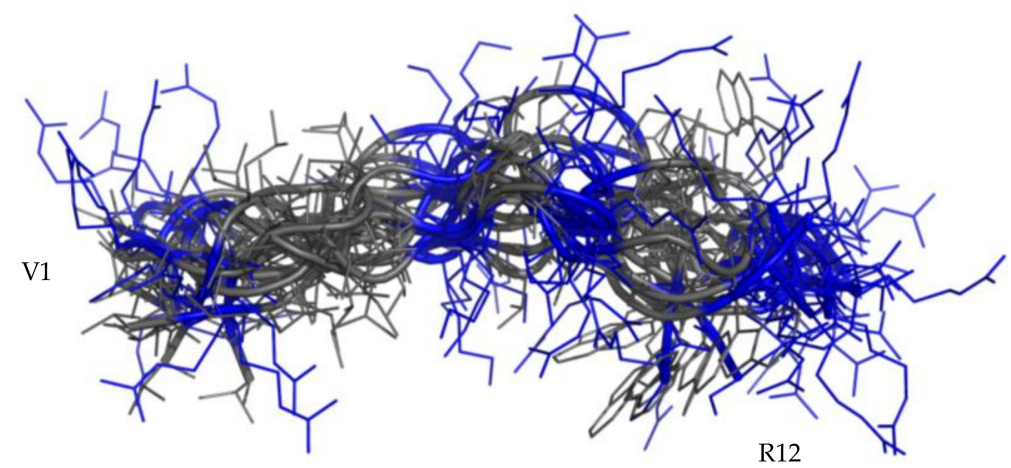

Figure 6. NMR structures of 1018-K6. Superimposition of 17 structures belonging to the main Chimera cluster representative of 1018-K6 conformation in water. Cartoon representation with hydrophobic side-chains as lines colored in gray and positive charged $(R, K)$ in blue. 


\subsubsection{NMR Analysis of RiLK1 in SDS Micelles}

The conformational NMR analysis was performed in a micellar environment of SDS/water mixture (150 mM SDS, pH 4.4) only for RiLK1, whilst 1018-K6 at millimolar concentration was found insoluble in this medium. In the micellar environment, RiLK1 adopts a relatively ordered structure. The negative $\alpha \mathrm{CH}$ deviations from random coil values $<-0.1 \mathrm{ppm}$ [48] (Supplementary Figure S10) point to a helical conformation in middle/C-terminal regions of the peptide. This structural diagnosis is consistent with the NOE pattern (Figure S11). Indeed, the presence of NOE effects, such as NHi-NHi+1, together with long range $\alpha \mathrm{i}-\mathrm{Ni}+2, \alpha \mathrm{i}-\mathrm{Ni}+3$ and $\alpha \mathrm{i}-\beta \mathrm{i}+3$ contacts, indicate the occurrence of a helical structure in the central region of the peptide. Structural calculations were carried out by CYANA [52] using $156 \mathrm{NOE-derived} \mathrm{distances} \mathrm{as} \mathrm{the} \mathrm{upper} \mathrm{limit} \mathrm{(upl)} \mathrm{of}$ inter-proton distances (130 intra-residues, 22 sequential, 4 long range), as reported in Table 1. The 40 lowest TF CYANA structures were clustered by the CHIMERA program [53]. The 20 structures contained in the first and most-populated cluster (Figure 5C) were chosen as representative of the conformational space accessible to the peptide. Their superimposition shows a well-defined structure in helix arrangement in K3-W8 segment (RMSD value on the backbone atoms of $0.26 \AA$ ) which places positively charged and hydrophobic side-chains on opposite sides. It is worth noticing that, in this arrangement, all the charged side-chains (R1, K3, R6, R9, R10) are iso-oriented and well prone to interact with the negatively charged surface of SDS micelles. Moreover, the two Trp side chains are located at a proper distance for mutual stacking, so contributing to the helix stabilization.

The atomic coordinates are deposited in the Protein Data Bank (PDB code 70B2).

Table 1. CYANA structural statistic of RiLK1 and 1018-K6 in different media.

\begin{tabular}{cccc}
\hline Structural Parameters & RiLK1 in SDS & RiLK1 in Water & 1018-K6 in Water \\
\hline distance restraints & 156 & 120 & 123 \\
intra-residue & 130 & 106 & 109 \\
sequential $(|\mathrm{i}-\mathrm{j}|=1)$ & 22 & 0 & 14 \\
Medium range $(1<|\mathrm{i}-\mathrm{j}| \leq 4)$ & 4 & 0 \\
CYANA TF $\left(\AA^{2}\right)$ & Violation Statistics $(40$ structures $)$ & $2.1 \times 10^{-2} \pm 2.1 \times 10^{-2}$ & $1.13 \times 10^{-2} \pm 9.9 \times 10^{-3}$ \\
number $>0.2 \AA$ & $0.26 \pm 0.02$ & 0 & 0 \\
mean global backbone RMSD & Residual Distance Constraint Violations $(\AA)$ & $2.60 \pm 0.42 \AA$ \\
mean global heavy atom RMSD & 0 & $2.15 \pm 0.41 \AA$ & $4.53 \pm 0.51 \AA$ \\
mean global heavy atom RMSD & $2.04 \pm 0.45 \AA$ & $4.36 \pm 0.58 \AA$ & \\
& $2.04 \pm 0.45 \AA$ & $4.36 \pm 0.58 \AA$ & \\
\hline
\end{tabular}

\section{Discussion}

The 12-mer 1018-K6 and the 10-mer RiLk1 are two peptides designed to function as antimicrobials, with the second one, rationally projected using the sequence of the first one as a template.

Previously, results demonstrated that RiLK1 exhibited a stronger killing efficiency than the 1018-K6 peptide against Listeria monocytogenes and Salmonella typhimurium, as well as against fungal pathogens [41].

The structural reasons that make RiLK1 a more efficient antimicrobial than 1018-K6 have been explored herein by comparing the two peptides, both with respect to their ability to self-aggregate, and for their conformational and interaction profiles with a bacterial membrane mimic.

The AFM analysis demonstrates that both RiLK1 and 1018-K6 are able to form ordered structures when their solutions are deposited on mica plates. Nevertheless, while 1018-K6 only aggregates at a low salt content, RiLK1 is organized into ordered aggregates both in water and in the presence of PBS, proving to be less sensitive to environmental conditions. 
In water and at $\mathrm{pH} \mathrm{4,} \mathrm{both} \mathrm{peptides} \mathrm{are} \mathrm{disordered,} \mathrm{while} \mathrm{they} \mathrm{interact} \mathrm{differently}$ with SDS micelles. As previously reported, the addition of SDS below the critical micellar concentration produces in both peptides the appearance of a beta conformation in equilibrium with a random structure [40,41]. However, in SDS micelles, 1018-K6 stabilizes almost $100 \%$ in beta-sheet structure, while RiLK1 shows the co-existence of multiple $\alpha$-helical and/or $\beta$-sheet-like subpopulations, which are in fast equilibrium with unordered states and whose formation is favored by the highly dynamic nature in the solution of small peptides like RiLK1. Therefore, the interaction with various proportions of SDS micelles could occur at several stages and a process of a simple two-state equilibrium could not sufficiently describe all the observed structural changes (Supplementary Table S1).

Interestingly, keeping the SDS concentration constant $(50 \mathrm{mM})$, the increase in the peptide concentration causes the stabilization of the beta structure in 1018-K6 in contrast to RiLK1, showing a more complex conformational distribution (Supplementary Table S2).

The effects of SDS on the peptide structure can derive from the variation of their chemical-physical properties, or from self-assembling processes, or be the result of a peptide-micelle interaction. In the latter case, the fact that RiLK1 in the presence of SDS shows the quenching of the fluorescence emission while 1018-K6 does not, which suggests that the interaction of RiLK1 with the SDS micelles is tighter than that of 1018-K6. This hypothesis is in line with the observation that RiLK1 is soluble at millimolar concentrations in the presence of $150 \mathrm{mM}$ SDS, while 1018-K6 is not. Since these conditions are those suitable for NMR measurements, only RiLK1 could be characterized in the presence of SDS micelles with this technique.

The NMR analysis confirms the CD structural diagnosis. In pure water, both peptides adopt iso-energetic disordered structures in fast inter-conversion on the NMR time scale (Figures 5 and 6), showing a random orientation of both charged and hydrophobic side chains. Notwithstanding, we found that approximately $25 \%$ of the structures calculated in water for RiLK1 exhibit a tendency to an amphiphilic arrangement (Figure 5B), which is definitively stabilized in the presence of SDS micelles (Figure 5C). In RiLK1, the Trp residue inserted in position 4 creates a hydrophobic cluster with the other Trp residue (W8). Such a modification affects the ability of RiLK1 to adopt amphipathic structures and improves the peptide binding to the micelles. Indeed, the structural model obtained by NMR for RiLK1 in SDS, shows a helix structure in the K3-W8 segment. The amphipathic helix is stabilized on one face by the presence of a Trp cluster and on the other by the interaction between the positively charged and the negatively charged SDS micelles.

The amphiphilic arrangement is functional to the formation of ordered self-aggregates. Indeed, the most investigated mechanisms of antimicrobial action foresee that peptides can act not only as single entities but also in self-assembled forms to form channels that pierce the membrane (pore mechanism) or to form layers that cover the membrane destabilizing it (a carpet-like mechanism) [25,54].

Although RiLK1 and 1018-K6 share 75\% of their sequence identity, their antibacterial activity, their behavior in terms of self-assembling, their conformational propensities and so their interaction skills with micelles, are different. The presence of SDS stabilizes the two peptides in ordered structures. The effect on 1018-K6 is to tighten its conformational distribution to the $100 \%$ of the beta form. Therefore, the micelles favor a beta-sheet selfassembling for 1018-K6 but further studies will be needed to establish its antibacterial mechanism of action.

On the contrary, the effect of SDS on RiLK1 is to widen the conformational distribution. The peptide is shorter and less prone to order than 1018-K6. Therefore, RiLK1 may have a wider spectrum of mechanisms of action, depending on the specific characteristics of the membrane with which it comes into contact. For all these features, RiLK1 represents a promising candidate for a new class of peptide-based antibiotics. 


\section{Materials and Methods}

\subsection{Optical and Atomic Force Microscopy}

RiLK1 and 1018-K6 were re-suspended in Dulbecco's phosphate buffered saline 1x (DPBS, Corning, Glendale, AZ, USA) or in phosphate buffer (PB) at different concentrations (40-80-160-240 $\mu \mathrm{M})$, in a 48 multi-well-dish $\left(200 \mu \mathrm{L} /\right.$ well), dried $\mathrm{O} / \mathrm{N}$ at $60^{\circ} \mathrm{C}$ and finally observed by stereomicroscope Leica MZ16-FA (Wetzlar, Germany) at different magnification. Images were recorded digitally with a Levenhuk M1000 PLUS camera (Levenhuk srl, Giulianova (TE), Italy). Sample preparation for the AFM study follows the procedure reported $[55,56]$. Briefly, muscovite mica is used as a superhydrophilic and atomically flat areas substrate with a wide presence of highly mobile $\mathrm{K}+$ ions after cleavage. The deposition of peptides was realized by casting $3 \mu \mathrm{L}$ aliquots for each imaged sample (RiLK1 and 1018-K6 in PBS or in water) onto a freshly cleaved muscovite mica. Each aliquot was left on the mica for $2 \mathrm{~min}$ to bind the $\mathrm{K}+$ charged mica surface and the negative domains of RiLK1 and 1018-K6 compound, and then extensively rinsed with deionized water (5 mL per sample) in order to completely remove salt crystals and the quote of peptide not bound to the mica surface. Therefore, the peptide samples were dried by evaporation at room temperature under a ventilated fume hood [57]. For AFM investigation, the concentrations of both peptides were $80 \mu \mathrm{M}$ in order to obtain the clearest images under dried conditions. The images were obtained by using A XE-100 AFM (Park Systems, Suwon, South Corea). Surface imaging was recorded in non-contact mode using silicon/aluminum coated cantilevers (SSS-NCHR 10M; Park Systems) $125 \mu \mathrm{m}$-long, with a resonance frequency of 204 to $397 \mathrm{kHz}$, a nominal force constant of $42 \mathrm{~N} / \mathrm{m}$ and a typical tip radius $2 \mathrm{~nm}(<5 \mathrm{~nm}$ max). The scan frequency was typically $0.5 \mathrm{~Hz}$ per line for $1064 \times 1064$-pixel image. Usually, the AFM images are flattened in order to remove the background slope and the contrast and brightness are adjusted. For each sample and for each concentration, the analyses were recorded three times.

\subsection{Spectroscopy}

Circular dichroism (CD) analysis was performed by the Jasco J-810 spectropolarimeter. The samples were loaded into a quartz cuvette of $0.1 \mathrm{~cm}$ path length (Hellma Italia srl, Milano, Italy) and the spectra were recorded in the 190-250 $\mathrm{nm}$ range at a scan speed of $20 \mathrm{~nm} / \mathrm{min}$, by averaging 5 scans and in the presence or absence of SDS (Sigma Aldrich, Milano, Italy). The effect of $\mathrm{pH}$ on the secondary structure of RiLK1 and 1018-K6 was evaluated by dissolving the samples at concentration of $50 \mathrm{i} \mu \mathrm{M}$ in water at $\mathrm{pH} 2.0, \mathrm{pH} 7.0$ and $\mathrm{pH}$ 12.0. Then, SDS ( $150 \mathrm{mM}$ final concentration) was added to each sample, which was incubated for further $48 \mathrm{~h}$ at $25^{\circ} \mathrm{C}$ and analyzed by $\mathrm{CD}$ spectroscopy. The folding kinetic measurements of the peptides were carried out after the addition of SDS (150 mM) to each sample (50 i $\mu \mathrm{M}$ in water $\mathrm{pH} 4.0$ ) up to $24 \mathrm{~h}$ incubation. CD experiments were also performed in water at $\mathrm{pH} 4.0$ as function of peptide concentration or SDS at a peptide concentration of $50 \mathrm{i} \mu \mathrm{M}$. For the thermal stability, the peptides were prepared to a final concentration of $50 \mu \mathrm{M}$ in water at $\mathrm{pH} 4.0$ in the presence of $150 \mathrm{mM}$ SDS, and then, they were incubated at 4,37 and $90^{\circ} \mathrm{C}$ up to $48 \mathrm{~h}$ before acquiring the $\mathrm{CD}$ spectra. In all analyses, the percentage of secondary structure was estimated by the DICHROWEB site [58-60],

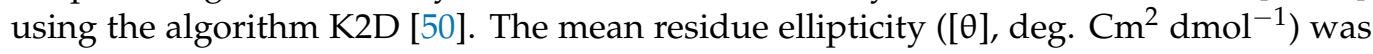
obtained by the equation $[\theta]=100 \theta / \mathrm{cnl}$, where $\theta$ is the ellipticity (mdeg), $\mathrm{c}$ is the peptide concentration $(\mathrm{mM}), \mathrm{n}$ is the number of residues, and $\mathrm{l}$ is the path length $(\mathrm{cm})$. For each sample, the background (buffer) was subtracted automatically from the signal.

\subsection{Fluorescence Spectroscopy}

Trp fluorescence emission spectra were recorded at $25{ }^{\circ} \mathrm{C}$ on a Shimadzu RF-6000 spectrofluorometer (Kyoto, Japan) with both excitation and emission slit widths set at $5 \mathrm{~nm}$. The intrinsic tryptophan was excited at a wavelength of $280 \mathrm{~nm}$ and the emission was monitored between 300 and $400 \mathrm{~nm}$. The folding kinetic experiments of RiLK1 and 1018-K6 were carried out after the addition of SDS $(150 \mathrm{mM})$ to each sample $(50 \mu \mathrm{M}$ concentration 
in water $\mathrm{pH} 4.0$ ) up to $24 \mathrm{~h}$ incubation. Fluorescence measurements were also performed in water $\mathrm{pH} 4.0$ as a function of peptide concentration or SDS at a peptide concentration of $50 \mu \mathrm{M}$. The effect of $\mathrm{pH}$ on peptide folding was evaluated by dissolving the peptides at a final concentration of $50 \mu \mathrm{M}$ in water at $\mathrm{pH} 2.0,7.0$ or 12.0 . Then, the SDS (150 mM final concentration) was added to each sample, which was incubated up to $48 \mathrm{~h}$ at $25^{\circ} \mathrm{C}$ and analyzed by fluorescence spectroscopy. For the thermal stability, the peptides were prepared to a final concentration of $50 \mu \mathrm{M}$ in water at $\mathrm{pH} 4.0$ in the presence of $150 \mathrm{mM}$ SDS and then they were incubated at 4,37 and $90^{\circ} \mathrm{C}$ up to $48 \mathrm{~h}$.

\subsection{NMR Spectroscopy}

The solution structures for NMR analysis of RiLK1 and 1018-K6 peptides were determined under different conditions: pure water $\left(\mathrm{H}_{2} \mathrm{O} / \mathrm{D}_{2} \mathrm{O} 90 / 10 \mathrm{v} / \mathrm{v}\right) \mathrm{pH} 4$ and in micellar SDS ( $\left.\mathrm{H}_{2} \mathrm{O} / \mathrm{SDS}-\mathrm{d} 25150 \mathrm{mM}, \mathrm{pH} 4.4\right)$. Deuterated water (98\% isotopic purity) and SDS-d25 (98\% isotopic purity) were purchased by Sigma Aldrich, Milano, Italy. NMR spectra were recorded on a Varian Unity Inova $700 \mathrm{MHz}$ Spectrometer located at the Department of Pharmacy-University of Naples "Federico II". The 2D 1H-NMR, TOCSY (mixing time $70 \mathrm{~ms}$ ) and NOESY (mixing time $300 \mathrm{~ms}$ ) were recorded at $298 \mathrm{~K}$. The water resonance was suppressed by the use of gradients. Chemical shifts were referred to internal sodium 3-(trimethylsilyl) propionate 2,2,3,3-d4 (TSP, Sigma Aldrich, Milano, Italy). NMR spectra were analyzed by using CARA program (http:/ / cara.nmr.ch/doku.php/home, accessed on 10 March 2021). Proton resonances were sequentially assigned by following the Wuthrich standard method [61].

NMR data were deposited in the Biological Magnetic Resonance Bank (BMRB entry 50902).

\subsection{Computational Methods}

NOE intensities, evaluated by the integration of cross-peaks in the $300 \mathrm{~ms}$ NOESY spectra, were converted into inter-proton distances by the use of the CALIBA program [62]. Geminal protons were chosen as the reference with a distance of $2.2 \AA$.

Structure calculations started from 100 randomized conformers and used the standard CYANA simulated annealing schedule with 20000 torsion angle dynamics steps per conformer [52]. Three dimensional structures were obtained by using inter-proton distances evaluated from NOEs as upper limits (Table 1). All the conformers showed fairly good agreement with the experimental constraints showing no violations. The best 40 CYANA structures out of 100 calculated structures, in terms of agreement with experimental data, i.e., with the lowest target function (TF) values (Table 1), were clustered by the CHIMERA program [53]. The molecular structures were visually analyzed by PyMOL software Molecular Graphics System, Version 2.0 Schrödinger, LLC.

\section{Patents}

Application No: PCT/IB2021/052519 Publication Date: 26/03/2021. Antimicrobial Peptides. BALESTRIERI MARCO, PALMIERI GIANNA, NICOLAIS LUIGI.

Supplementary Materials: The following are available online at https:/ / www.mdpi.com/article/10 .3390/ijms221810011/s1, Figure S1: Stereomicroscopic analysis of RILK1 and 1018-K6 in PBS; Figure S2: Stereomicroscopic analysis of RILK1 and 1018-K6 in PB; Figure S3: CD (left) and fluorescence (right) spectra of RiLK1 at increasing peptide concentration; Figure S4: CD (left) and fluorescence (right) spectra of 1018-K6 at increasing peptide concentration; Figure S5: Effect of $\mathrm{pH}$ on the folding and secondary structure of 1018-K6 monitored by spectroscopic techniques; Figure S6: Effect of pH on the folding and secondary structure of RiLK1 monitored by spectroscopic techniques; Figure S7: Thermostability of 1018-K6 monitored by spectroscopic techniques; Figure S8: Thermostability of RiLK1 monitored by spectroscopic techniques; Figure S9: 1H NMR spectra of RiLK1 1.0 mM; Figure S10: Chemical shift deviations (ppm) from random coil values of aCH protons; Figure S11: Most relevant NOE effects measured for RiLK1 peptide in SDS; Table S1: Secondary structure contents of (A) RiLK1 and (B) 1018-K6 at $50 \mu \mathrm{M}$ concentration in water $\mathrm{pH} 4$ in the presence of different concentrations of SDS determined by the Dichroweb server (K2D); Table S2: Secondary structure 
contents of (A) RiLK1 and (B) 1018-K6 at different concentrations in water $\mathrm{pH} 4.0$ in the presence of $50 \mu \mathrm{M}$ SDS determined by the Dichroweb server (K2D); Table S3: Secondary structure contents of (A) 1018-K6 and (B) RiLK1 $50 \mu \mathrm{M}$ concentration in water $\mathrm{pH} 4$ in the presence of $150 \mathrm{mM}$ SDS at different times determined by the Dichroweb server (K2D); Table S4: Secondary structure contents of (A) 1018-K6 and (B) RiLK1 at $50 \mu \mathrm{M}$ concentration in water at different pHs in the presence of 150 mM SDS determined by the Dichroweb server (K2D); Table S5: Secondary structure contents of (A) 1018-K6 and (B) RiLK1 at $50 \mu \mathrm{M}$ concentration in water $\mathrm{pH} 4.0$ in the presence of $150 \mathrm{mM}$ SDS at different temperatures determined by the Dichroweb server (K2D).

Author Contributions: Conceptualization, L.F., G.D., P.D., R.T. and G.P.; methodology, B.A., G.D., R.T. and P.D.; software, L.F. and G.D.; validation, M.B. and M.G.; formal analysis, B.A., L.F., R.T. and P.D.; investigation, L.F., B.A. and G.D.; resources, G.P. and L.N.; data curation, M.G. and G.D.; writing-original draft preparation, G.D. and M.B.; writing-review and editing, L.F., M.G. and G.P.; visualization, M.G., M.B. and G.P.; supervision, L.N.; project administration, G.P.; funding acquisition, G.P. and L.N. All authors have read and agreed to the published version of the manuscript.

Funding: This research was funded by: Ministero della Salute-“ Attività battericida ed anti-biofilm di nano-sistemi ibridi coniugati con peptidi antimicrobici: una nuova strategia per la formulazione di bio-sanitizzanti contro ceppi patogeni resistenti"-Ricerca Corrente 2018 project, grant number IZS ME 06/18 RC; Ministero dello Sviluppo Economico "Packaging Bioattivi e bIOsanitizzanti: Sviluppo di stratEgie iNnovaTIve ed ecososteNibili pEr L'Industria Alimentare-(BIO-SENTINEL) project, grant number F/200092/01-03/X45. Fondo per la Crescita Sostenibile-Sportello "Agrifood" PON I\&C 2014-2020; Ministero della Salute—“Dalle superfici agli alimenti: nuove soluzioni per alimenti più sicuri (NewSan)—Ricerca Corrente 2020 project, grant number IZSME 06/20 RC.

Institutional Review Board Statement: Not applicable.

Informed Consent Statement: Not applicable.

Data Availability Statement: The NMR structures of RiLK1 in SDS are available in the Protein Data Bank: PDB code 70B2. Proton chemical shifts of RiLK1 in SDS are available in Biological Magnetic Resonance Bank: BMRB entry 50902.

Acknowledgments: The authors would like to thank Giovanni Del Monaco and Chiara Nobile for their technical assistance.

Conflicts of Interest: The authors declare no conflict of interest. The funders had no role in the design of the study; in the collection, analyses, or interpretation of the data; in the writing of the manuscript, or in the decision to publish the results.

\section{References}

1. Boullet, H.; Bentot, F.; Hequet, A.; Ganem-Elbaz, C.; Bechara, C.; Pacreau, E.; Launay, P.; Sagan, S.; Jolivalt, C.; Lacombe, C.; et al. Small antimicrobial peptide with in vivo activity against sepsis. Molecules 2019, 24, 1702. [CrossRef]

2. Piotrowska, U.; Sobczak, M.; Oledzka, E. Current state of a dual behaviour of antimicrobial peptides-therapeutic agents and promising delivery vectors. Chem. Biol. Drug Des. 2017, 90, 1079-1093. [CrossRef] [PubMed]

3. Yazici, A.; Ortucu, S.; Taskin, M.; Marinelli, L. Natural-based antibiofilm and antimicrobial peptides from microorganisms. Curr. Top. Med. Chem. 2018, 18, 2102-2107. [CrossRef]

4. Huang, Y.; Huang, J.; Chen, Y. Alpha-helical cationic antimicrobial peptides: Relationships of structure and function. Protein Cell 2010, 1, 143-152. [CrossRef] [PubMed]

5. Agrillo, B.; Balestrieri, M.; Gogliettino, M.; Palmieri, G.; Moretta, R.; Proroga, Y.T.R.; Rea, I.; Cornacchia, A.; Capuano, F.; Smaldone, G.; et al. Functionalized polymeric materials with bio-derived antimicrobial peptides for "active" packaging. Int. J. Mol. Sci. 2019, 20, 601. [CrossRef]

6. Festa, R.; Ambrosio, R.L.; Lamas, A.; Gratino, L.; Palmieri, G.; Franco, C.M.; Cepeda, A.; Anastasio, A. A study on the antimicrobial and antibiofilm peptide 1018-k6 as potential alternative to antibiotics against food-pathogen salmonella enterica. Foods 2021, 10, 1372. [CrossRef]

7. Gogliettino, M.; Balestrieri, M.; Ambrosio, R.L.; Anastasio, A.; Smaldone, G.; Proroga, Y.T.R.; Moretta, R.; Rea, I.; De Stefano, L.; Agrillo, B.; et al. Extending the shelf-life of meat and dairy products via pet-modified packaging activated with the antimicrobial peptide mtp1. Front. Microbiol. 2019, 10, 2963. [CrossRef] [PubMed]

8. Keymanesh, K.; Soltani, S.; Sardari, S. Application of antimicrobial peptides in agriculture and food industry. World J. Microb. Biotechnol. 2009, 25, 933-944. [CrossRef] 
9. Palmieri, G.; Balestrieri, M.; Proroga, Y.T.; Falcigno, L.; Facchiano, A.; Riccio, A.; Capuano, F.; Marrone, R.; Neglia, G.; Anastasio, A. New antimicrobial peptides against foodborne pathogens: From in silico design to experimental evidence. Food Chem. 2016, 211, 546-554. [CrossRef]

10. Palmieri, G.; Tate, R.; Gogliettino, M.; Balestrieri, M.; Rea, I.; Terracciano, M.; Proroga, Y.T.; Capuano, F.; Anastasio, A.; De Stefano, L. Small synthetic peptides bioconjugated to hybrid gold nanoparticles destroy potentially deadly bacteria at submicromolar concentrations. Bioconjug. Chem. 2018, 29, 3877-3885. [CrossRef]

11. Wang, S.; Zeng, X.; Yang, Q.; Qiao, S. Antimicrobial peptides as potential alternatives to antibiotics in food animal industry. Int. J. Mol. Sci. 2016, 17, 603. [CrossRef]

12. Rai, M.; Pandit, R.; Gaikwad, S.; Kovics, G. Antimicrobial peptides as natural bio-preservative to enhance the shelf-life of food. J. Food Sci. Technol. 2016, 53, 3381-3394. [CrossRef] [PubMed]

13. Moreno, M.G.; Lombardi, L.; Di Luca, M. Antimicrobial peptides for the control of biofilm formation. Curr. Top. Med. Chem. 2017, 17, 1965-1986. [CrossRef]

14. Pletzer, D.; Coleman, S.R.; Hancock, R.E. Anti-biofilm peptides as a new weapon in antimicrobial warfare. Curr. Opin. Microbiol. 2016, 33, 35-40. [CrossRef] [PubMed]

15. Jenssen, H.; Hamill, P.; Hancock, R.E. Peptide antimicrobial agents. Clin. Microbiol. Rev. 2006, 19, 491-511. [CrossRef]

16. Bahar, A.A.; Ren, D. Antimicrobial peptides. Pharmaceuticals 2013, 6, 1543-1575. [CrossRef]

17. Kang, H.K.; Kim, C.; Seo, C.H.; Park, Y. The therapeutic applications of antimicrobial peptides (amps): A patent review. J. Microbiol. 2017, 55, 1-12. [CrossRef]

18. Saravanan, R.; Li, X.; Lim, K.; Mohanram, H.; Peng, L.; Mishra, B.; Basu, A.; Lee, J.M.; Bhattacharjya, S.; Leong, S.S. Design of short membrane selective antimicrobial peptides containing tryptophan and arginine residues for improved activity, salt-resistance, and biocompatibility. Biotechnol. Bioeng. 2014, 111, 37-49. [CrossRef]

19. Chen, Y.; Guarnieri, M.T.; Vasil, A.I.; Vasil, M.L.; Mant, C.T.; Hodges, R.S. Role of peptide hydrophobicity in the mechanism of action of alpha-helical antimicrobial peptides. Antimicrob. Agents Chemother. 2007, 51, 1398-1406. [CrossRef]

20. Vaezi, Z.; Bortolotti, A.; Luca, V.; Perilli, G.; Mangoni, M.L.; Khosravi-Far, R.; Bobone, S.; Stella, L. Aggregation determines the selectivity of membrane-active anticancer and antimicrobial peptides: The case of killerflip. Biochim. Biophys. Acta Biomembr. 2020, 1862, 183107-183115. [CrossRef]

21. Liscano, Y.; Salamanca, C.H.; Vargas, L.; Cantor, S.; Laverde-Rojas, V.; Onate-Garzon, J. Increases in hydrophilicity and charge on the polar face of alyteserin 1c helix change its selectivity towards gram-positive bacteria. Antibiotics 2019, 8, 238. [CrossRef]

22. Liu, R.; Hudalla, G.A. Using self-assembling peptides to integrate biomolecules into functional supramolecular biomaterials. Molecules 2019, 24, 1450. [CrossRef]

23. Yeaman, M.R.; Yount, N.Y. Mechanisms of antimicrobial peptide action and resistance. Pharmacol. Rev. 2003, 55, 27-55. [CrossRef]

24. Aoki, W.; Ueda, M. Characterization of antimicrobial peptides toward the development of novel antibiotics. Pharmaceuticals 2013, 6, 1055-1081. [CrossRef] [PubMed]

25. Lee, T.H.; Hall, K.N.; Aguilar, M.I. Antimicrobial peptide structure and mechanism of action: A focus on the role of membrane structure. Curr. Top. Med. Chem. 2016, 16, 25-39. [CrossRef] [PubMed]

26. Zelezetsky, I.; Tossi, A. Alpha-helical antimicrobial peptides-Using a sequence template to guide structure-activity relationship studies. Biochim. Biophys. Acta 2006, 1758, 1436-1449. [CrossRef]

27. Seo, M.D.; Won, H.S.; Kim, J.H.; Mishig-Ochir, T.; Lee, B.J. Antimicrobial peptides for therapeutic applications: A review. Molecules 2012, 17, 12276-12286. [CrossRef] [PubMed]

28. Carratala, J.V.; Serna, N.; Villaverde, A.; Vazquez, E.; Ferrer-Miralles, N. Nanostructured antimicrobial peptides: The last push towards clinics. Biotechnol. Adv. 2020, 44, 107603-107615. [CrossRef]

29. Chen, L.; Liang, J.F. Peptide fibrils with altered stability, activity, and cell selectivity. Biomacromolecules 2013, $14,2326-2331$. [CrossRef] [PubMed]

30. Chen, L.; Patrone, N.; Liang, J.F. Peptide self-assembly on cell membranes to induce cell lysis. Biomacromolecules 2012, 13, 3327-3333. [CrossRef] [PubMed]

31. Lombardi, L.; Shi, Y.; Falanga, A.; Galdiero, E.; de Alteriis, E.; Franci, G.; Chourpa, I.; Azevedo, H.S.; Galdiero, S. Enhancing the potency of antimicrobial peptides through molecular engineering and self-assembly. Biomacromolecules 2019, 20, 1362-1374. [CrossRef]

32. Shen, Z.; Guo, Z.; Zhou, L.; Wang, Y.; Zhang, J.; Hu, J.; Zhang, Y. Biomembrane induced in situ self-assembly of peptide with enhanced antimicrobial activity. Biomater. Sci. 2020, 8, 2031-2039. [CrossRef]

33. Palmieri, G.; Balestrieri, M.; Capuano, F.; Proroga, Y.T.R.; Pomilio, F.; Centorame, P.; Riccio, A.; Marrone, R.; Anastasio, A. Bactericidal and antibiofilm activity of bactenecin-derivative peptides against the food-pathogen listeria monocytogenes: New perspectives for food processing industry. Int. J. Food Microbiol. 2018, 279, 33-42. [CrossRef] [PubMed]

34. Wieczorek, M.; Jenssen, H.; Kindrachuk, J.; Scott, W.R.; Elliott, M.; Hilpert, K.; Cheng, J.T.; Hancock, R.E.; Straus, S.K. Structural studies of a peptide with immune modulating and direct antimicrobial activity. Chem. Biol. 2010, 17, 970-980. [CrossRef] [PubMed]

35. Kościuczuk, E.M.; Lisowski, P.; Jarczak, J.; Strzałkowska, N.; Jóźwik, A.; Horbańczuk, J.; Krzyżewski, J.; Zwierzchowski, L.; Bagnicka, E. Cathelicidins: Family of antimicrobial peptides. A review. Mol. Biol. Rep. 2012, 39, 10957-10970. [CrossRef] [PubMed] 
36. de la Fuente-Nunez, C.; Reffuveille, F.; Haney, E.F.; Straus, S.K.; Hancock, R.E. Broad-spectrum anti-biofilm peptide that targets a cellular stress response. PLoS Pathog. 2014, 10, e1004152. [CrossRef]

37. Reffuveille, F.; de la Fuente-Nunez, C.; Mansour, S.; Hancock, R.E. A broad-spectrum antibiofilm peptide enhances antibiotic action against bacterial biofilms. Antimicrob. Agents Chemother. 2014, 58, 5363-5371. [CrossRef]

38. Rivas-Santiago, B.; Castaneda-Delgado, J.E.; Rivas Santiago, C.E.; Waldbrook, M.; Gonzalez-Curiel, I.; Leon-Contreras, J.C.; Enciso-Moreno, J.A.; del Villar, V.; Mendez-Ramos, J.; Hancock, R.E.; et al. Ability of innate defence regulator peptides idr-1002, idr-hh2 and idr-1018 to protect against mycobacterium tuberculosis infections in animal models. PLoS ONE 2013, 8, e59119. [CrossRef]

39. Steinstraesser, L.; Hirsch, T.; Schulte, M.; Kueckelhaus, M.; Jacobsen, F.; Mersch, E.A.; Stricker, I.; Afacan, N.; Jenssen, H.; Hancock, R.E.; et al. Innate defense regulator peptide 1018 in wound healing and wound infection. PLoS ONE 2012, 7, e39373. [CrossRef]

40. Colagiorgi, A.; Festa, R.; Di Ciccio, P.A.; Gogliettino, M.; Balestrieri, M.; Palmieri, G.; Anastasio, A.; Ianieri, A. Rapid biofilm eradication of the antimicrobial peptide 1018-k6 against staphylococcus aureus: A new potential tool to fight bacterial biofilms. Food Control. 2020, 107, 106815-106821. [CrossRef]

41. Agrillo, B.; Proroga, Y.T.R.; Gogliettino, M.; Balestrieri, M.; Tate, R.; Nicolais, L.; Palmieri, G. A safe and multitasking antimicrobial decapeptide: The road from de novo design to structural and functional characterization. Int. J. Mol. Sci. 2020, 21, 6952. [CrossRef]

42. Powers, J.P.; Hancock, R.E. The relationship between peptide structure and antibacterial activity. Peptides 2003, 24, 1681-1691. [CrossRef]

43. Chan, D.I.; Prenner, E.J.; Vogel, H.J. Tryptophan- and arginine-rich antimicrobial peptides: Structures and mechanisms of action. Biochim. Biophys. Acta 2006, 1758, 1184-1202. [CrossRef]

44. Bi, X.; Wang, C.; Dong, W.; Zhu, W.; Shang, D. Antimicrobial properties and interaction of two trp-substituted cationic antimicrobial peptides with a lipid bilayer. J. Antibiot. 2014, 67, 361-368. [CrossRef]

45. Mikut, R.; Ruden, S.; Reischl, M.; Breitling, F.; Volkmer, R.; Hilpert, K. Improving short antimicrobial peptides despite elusive rules for activity. Biochim. Biophys. Acta 2016, 1858, 1024-1033. [CrossRef]

46. Yau, W.M.; Wimley, W.C.; Gawrisch, K.; White, S.H. The preference of tryptophan for membrane interfaces. Biochemistry 1998, 37, 14713-14718. [CrossRef]

47. Tanford, C.; Reynolds, J.A. Characterization of membrane proteins in detergent solutions. Biochim. Biophys. Acta 1976, 457, 133-170. [CrossRef]

48. Oliveira, N.G.J.; Cardoso, M.H.; Velikova, N.; Giesbers, M.; Wells, J.M.; Rezende, T.M.B.; de Vries, R.; Franco, O.L. Physicochemicalguided design of cathelicidin-derived peptides generates membrane active variants with therapeutic potential. Sci. Rep. 2020, 10, 9127. [CrossRef] [PubMed]

49. Hong, Z.; Damodaran, K.; Asher, S.A. Sodium dodecyl sulfate monomers induce XAO peptide polyproline II to $\alpha$-helix transition. J. Phys. Chem. B 2014, 118, 10565-10575. [CrossRef] [PubMed]

50. Perez-Iratxeta, C.; Andrade-Navarro, M.A. K2d2: Estimation of protein secondary structure from circular dichroism spectra. BMC Struct. Biol. 2008, 8, 25-29. [CrossRef] [PubMed]

51. Wishart, D.S.; Sykes, B.D.; Richards, F.M. Relationship between nuclear magnetic resonance chemical shift and protein secondary structure. J. Mol. Biol. 1991, 222, 311-333. [CrossRef]

52. Guntert, P. Automated nmr structure calculation with cyana. Methods Mol. Biol. 2004, 278, 353-378. [PubMed]

53. Pettersen, E.F.; Goddard, T.D.; Huang, C.C.; Couch, G.S.; Greenblatt, D.M.; Meng, E.C.; Ferrin, T.E. Ucsf chimera-a visualization system for exploratory research and analysis. J. Comput. Chem. 2004, 25, 1605-1612. [CrossRef]

54. Kumar, P.; Kizhakkedathu, J.N.; Straus, S.K. Antimicrobial peptides: Diversity, mechanism of action and strategies to improve the activity and biocompatibility in vivo. Biomolecules 2018, 8, 4. [CrossRef]

55. Artini, M.; Cicatiello, P.; Ricciardelli, A.; Papa, R.; Selan, L.; Dardano, P.; Tilotta, M.; Vrenna, G.; Tutino, M.L.; Giardina, P.; et al. Hydrophobin coating prevents staphylococcus epidermidis biofilm formation on different surfaces. Biofouling 2017, 33, 601-611. [CrossRef]

56. Oliviero, G.; D’Errico, S.; Pinto, B.; Nici, F.; Dardano, P.; Rea, I.; De Stefano, L.; Mayol, L.; Piccialli, G.; Borbone, N. Self-assembly of g-rich oligonucleotides incorporating a $3^{\prime}-3^{\prime}$ inversion of polarity site: A new route towards g-wire DNA nanostructures. ChemistryOpen 2017, 6, 599-605. [CrossRef] [PubMed]

57. Lyubchenko, Y.L.; Shlyakhtenko, L.S. AFM for analysis of structure and dynamics of DNA and protein-DNA complexes. Methods 2009, 47, 206-213. [CrossRef] [PubMed]

58. Lobley, A.; Whitmore, L.; Wallace, B.A. Dichroweb: An interactive website for the analysis of protein secondary structure from circular dichroism spectra. Bioinformatics 2002, 18, 211-212. [CrossRef]

59. Whitmore, L.; Wallace, B.A. Dichroweb, an online server for protein secondary structure analyses from circular dichroism spectroscopic data. Nucleic Acids Res. 2004, 32, W668-W673. [CrossRef]

60. Whitmore, L.; Wallace, B.A. Protein secondary structure analyses from circular dichroism spectroscopy: Methods and reference databases. Biopolymers 2008, 89, 392-400. [CrossRef]

61. Wuthrich, K. NMR of Proteins and Nucleic Acids; Wiley: New York, NY, USA, 1986; pp. 1-320.

62. Guntert, P.; Qian, Y.Q.; Otting, G.; Muller, M.; Gehring, W.; Wuthrich, K. Structure determination of the Antp(c39 $\rightarrow$ s) homeodomain from nuclear magnetic resonance data in solution using a novel strategy for the structure calculation with the programs diana, caliba, habas and glomsa. J. Mol. Biol. 1991, 217, 531-540. [CrossRef] 